www.jmscr.igmpublication.org

Impact Factor 5.244

Index Copernicus Value: 83.27

ISSN (e)-2347-176x ISSN (p) 2455-0450

crossref DOI: _https://dx.doi.org/10.18535/jmscr/v4i10.51

Journal Of Medical Science And Clinical Research

\title{
Complications of Renal Biopsy A Single Centre Experience
}

\author{
Authors \\ Dr Ashaq Hussain Parrey ${ }^{1}$, Dr Khurshid Ahmad Banday², Dr Imtiyaz Ahmad ${ }^{3}$, \\ Dr Mir Waseem ${ }^{4}$ \\ ${ }^{1,2,3}$ Deptt. of Nephrology SKIMS Medical Institute Soura, Srinagar, India \\ ${ }^{4}$ Deptt.of Medicine SKIMS Medical Institute Soura, Srinagar, India \\ Corresponding Author \\ Dr Ashaq Hussain Parrey \\ Deptt.of Nephrology SKIMS Medical Institute Soura, Srinagar, India \\ Married Doctors Hostel SKIMS Medical Institute, Pin. Code:-19001 \\ Email:-chogalpora@gmail.com, Mobile No.9419586992
}

\begin{abstract}
Introduction: Renal biopsy is a procedure in which a sample of renal tissue is obtained for diagnosis of renal diseases. Major complications of renal biopsy include gross hematuria or retroperitoneal hematoma requiring blood transfusion, invasive procedure or surgical intervention and rarely sepsis.

Aims and Objectives:-To study the complications of renal biopsy.

Materials and Methods: In this prospective study 345 patients underwent renal biopsy over 2.5 years from 2009 to 2012.

Results: In this prospective study 345 renal biopsies were performed in 210 males (60.9\%) and 135 females (39.1\%). The mean age of males were $36 \pm 14.3$ and in females mean age was $29.6+12.8$ the most common age group biopsied was between 19-45yrs of age both among males (58.6\%) and females (66.7) respectively. The number of patients below 18yrs of age were 63 (18.3\%), 33 male and 30 female. Patients above the age of 45 were 69 (20\%) 54 males and 15 females. Pain was the most common complication in our study out of 345 patients 141 (40.9\%) complained of some sort of pain during initial 24 hrs of hospital stay. Second most common complication was gross hematuria 69 patients (20\%), hematoma in $9.3 \%$, pylonephritis in $0.9 \%$, AV fistula 0.9\%. There was increased incidence of gross hematuria and hypotension in patients with prolonged prothrombin time with $P$ value $=0.035$.

Conclusion: The complications do occur with renal biopsy, but with proper pre and post procedure management they can be reduced significantly if not eliminated at all. In our study prolonged prothrombin time was associated with increased risk of hypotension and hematuria.

Keywords:-Renal, biopsy, complications.
\end{abstract}

\section{Introduction}

The procedure of obtaining and examining a small tissue sample from the kidney is known renal biopsy. Percutaneous renal biopsy was first descrybed in the early 1950 s by Iversen and Brun ${ }^{[1]}$ and Alwall ${ }^{[2]}$ In the following years the technique 
increased its diagnostic potential with the development of immunofluorescence microscopy and electron microscopy. Thus, renal biopsy became a crucial means for establishing the knowledge of histopathology, pathogenesis and classification of renal disease ${ }^{[3]}$. At present with the use of real time ultrasound and automated needles $>99 \%$ biopsies are diagnostic ${ }^{[4]}$. There is no doubt that percutaneous renal biopsy is extremely useful in clinical nephrology to establish an accurate diagnosis, to obtain data of prognostic value and to chose the most appropriate treatment for most patients affected by renal disease. Nevertheless, the morbidity and occasional mortality associated with this procedure require a careful evaluation of the risk to benefit ratio for each patient. This evaluation, however, is quite subjective ${ }^{[5,6]}$. Thus, it is not surprising that the indications for kidney biopsy vary considerably among nephrologists ${ }^{[7,8]}$.

Although minor complications can occur in as high as $19.5 \%$ patients ${ }^{[9]}$, however serious complications are infrequent. Factors that have been found to predispose to complications after PRB include renal insufficiency (>1.2 mg/dl), poorly controlled hypertension (diastolic BP $>90$ to $110 \mathrm{mmHg}$ ), and a prolonged bleeding time $[10,11]$. The significant complications related to renal biopsy are hemorrhage, development of arteriovenous fistulas, and to a lesser extent sepsis, the risks of complication vary from center to center and between practitioners but can be estimated to be between $3.5 \%$ and $13 \%$, with the majority being minor complications (approximately $3 \%$ to $9 \%)^{[12,13,14]}$. Hematuria with drop in hemoglobin of $\geq 1 \mathrm{~g} / \mathrm{dl}$ after biopsy is common and has been reported to occur in almost $50 \%$ of patients ${ }^{[15,16,17]}$

Aims and Objectives: - To study complications of renal biopsy.

\section{Materials and Methods}

This prospective study was conducted in department of nephrology Sher-i-kashmir institute of medical sciences. 345 patients who underwent renal biopsy in two and half years from 2009 to 2012.

Subjects: Patients who presented with clinical and/or laboratory features of renal disease were subjected to renal biopsy. All these patients were subjected to ultrasound guided Percutaneous Renal biopsy after ruling out cause of renal disease by other noninvasive methods. The information which was collected before biopsy included, Age, Sex, History of illness, Blood Pressure, KFT, Bleeding time clotting time, activated partial thromboplastin time, Partial thromboplastin time, complete blood count, 24 hour urinary protein, routine urine examination, hepatitis B, C and HIV serology.

The indications for the biopsy were as listed below:

1. Protinuria and Hematuria.

2. Subnephrotic Protinuria.

3. Nephrotic syndrome.

4. ATN not recovering in 4 weeks.

5. Systemic Disease (e,g Vasculitis).

6. Subnephrotic Protinuria wih azotemia.

7. Post renal transplant azotemia.

8. Gross hematuria.

Procedure:- Percutaneous renal biopsy was performed with an automated spring loaded device with needle size of 14 to $18 \mathrm{G}$. The skin and subcutaneous tissue was anesthetized with lidocaine followed by deeper anesthesia with a spinal needle. The depth on was noted with an ultrasonogram and was confirmed with spinal needle. All the biopsies were done under the guidance of ultrasonogram. The biopsy needle was then introduced to the depth and engaged if the renal tissue was not obtained a deeper biopsy was performed. The biopsy was repeated until an adequate amount of tissue was obtained (usually three specimens). After the procedure patient was advised to lie flat on bed on his back and no activity was allowed for six hours and was observed for $24 \mathrm{hrs}$ for any complication. Patient 
blood pressure for initial 3 hours was monitored every 30 minutes then hourly for 5 hours then 4 hourly for $16 \mathrm{hrs}$. Patient was monitored for Hematuria, pain, fever, and any other complication post biopsy Hemoglobin was done after 24hrs of biopsy to see for drop in hemoglobin. Patient was reviewed after one week on OPD basis and USG abdomen was done to rule out AV fistula.

\section{Results}

In this prospective study 345 renal biopsies were performed 210 males $(60.9 \%)$ and 135 females (39.1\%). The mean age of males were $36 \pm 14.3$ and in females mean age was $29.6+12.8$ the most common age group biopsied was between 1945yrs of age both among males (58.6\%) and females (66.7). The number of patients below $18 \mathrm{yrs}$ of age were 63 (18.3\%), 33 male and 30 female. Patients above the age of 45 were 69 (20\%) 54 male and 15 females (Table-1).

Table 1. Showing age and gender distribution

\begin{tabular}{|c|c|c|c|c|c|c|}
\hline \multirow{2}{*}{ Age (yr) } & \multicolumn{2}{|c|}{ Male } & \multicolumn{2}{c|}{ Female } & \multicolumn{2}{c|}{ Total } \\
\cline { 2 - 6 } & $\mathrm{N}$ & $\%$ & $\mathrm{~N}$ & $\%$ & $\mathrm{~N}$ & 63 \\
\hline$\leq 18$ & 33 & 15.7 & 30 & 22.2 & $63.3 \%$ \\
\hline 19 to 45 & 123 & 58.6 & 90 & 66.7 & 213 & $61.7 \%$ \\
\hline$>45$ & 54 & 25.7 & 15 & 11.1 & 69 & $20.0 \%$ \\
\hline Total & 210 & 60.9 & 135 & 39.1 & 345 & $100 . \%$ \\
\hline mean \pm SD & $36.0 \pm 14.3(9,70)$ & $29.6 \pm 12.8(13,60)$ & $33.5+14.0(9,70)$ \\
\hline
\end{tabular}

In our study of 345 patients the indication for renal biopsy was Protinuria and Hematuria (22\%) isolated subnephrotic protinuria (22.6\%) Nephrotic syndrome (21.7\%) ARP (5; 2\%) systemic disease (3.5\%) Subnephrotic Protinuria wih azotemia (20\%) and post renal transplant azoteamia.

Pain was the most common complication in our study out of 345 patients 141 (40.9\%) complained of some sort of pain during first $24 \mathrm{hrs}$ of hospital stay however only $26 \%$ patients needed analgesia while rest were able to tolerate pain which was mostly posture related,

The second most common complication was gross hematuria in 69patients (20\%) which was evident in initial $12 \mathrm{hrs}$ in almost all 69 patients post biopsy.51 patients $(14.8 \%$ ) had greater than $2 \mathrm{~g}$ drop in haemoglobin however the hematuria settled within $24 \mathrm{hrs}$ in 54 patient after biopsy the hematuria persisted in 15 patients $(4.3 \%)$ for more than $24 \mathrm{hrs}$ and these patients had drop of hemoglobin by more than $2 \mathrm{~g} / \mathrm{dl}$ and needed blood transfusion for stabilizing hemodynomics. Gross hematuria for more than $24 \mathrm{hrs}$ especially if patient becomes hemodynomically unstable in considered as major complication of renal biopsy. The study revealed that patients with prolonged PT (prothrombin time) have increased incidence of drop in hemoglobin and hypotension (Table-2).

Table 2. Showing complications of renal biopsy in our study

\begin{tabular}{|c|c|c|}
\hline Complication & No.of patients & $\%$ \\
\hline Gross Hematuria & 69 & 20.0 \\
\hline Pain & 141 & 40.9 \\
\hline Infection & 3 & 0.9 \\
\hline Hematoma & 33 & 9.6 \\
\hline A V Fistula & 3 & 0.9 \\
\hline Hypotension & 15 & 4.3 \\
\hline Need for Blood Transfusion & 15 & 4.3 \\
\hline
\end{tabular}

\section{Discussion}

In our study there was no mortality and no need for an invasive procedure, like nephrectomy,oe embolisation. Nonetheless, complications did occur in $20 \%$ of biopsies, and $5.2 \%$ of complications were considered major, primarily because of the need for transfusion after biopsy in $4.3 \%$ (Table-3) cases, and sepsis in $0.9 \%$ paients (Table2). Lefaucheur et al [8] reported 6 to $7 \%$ incidence of major complications that is need for blood transfusion and/or need of surgical procedure to stabilize the patient. 
Table 3. Showing pre and post biopsy hemoglobin .greater than $2 \mathrm{~g} / \mathrm{dl}$ drop in hemoglobin was noticed in $14.8 \%$ patients.

\begin{tabular}{|c|c|c|c|c|}
\hline & \multicolumn{2}{|c|}{$\begin{array}{c}\text { No.of } \\
\text { patients }\end{array}$} & $\%$ & p value \\
\hline \multicolumn{2}{|c|}{ Baseline Hemoglobin (gm \%) } & \multicolumn{2}{|c|}{$10.98 \pm 2.38(7.0,16.3)$} & \\
\hline \multicolumn{2}{|c|}{ Post Biopsy Hemoglobin (gm \%) } & $10.15 \pm 2.19(5.1,15.3)$ & \\
\hline \multirow{3}{*}{ Drop in $\mathrm{Hb}$} & Unchanged & 48 & 13.9 & \multirow{3}{*}{0.000 (Sig) } \\
\cline { 2 - 4 } & $<1.0$ & 177 & 51.3 & \\
\cline { 2 - 4 } & 1.0 to 2.0 & 69 & 20.0 & \\
\cline { 2 - 4 } & $>2.0$ & 51 & 14.8 & \\
\hline
\end{tabular}

Post biopsy hemoglobin remained unchanged in 48 patients (13.9\%). Drop in hemoglobin less than $1 \mathrm{~g} / \mathrm{dl}$ was noticed in 177 patients $(51.3 \%), 1-2$ $\mathrm{g} / \mathrm{dl}$ drop in hemoglobin was seen in 69 patients (20\%) and significant drop of more $2 \mathrm{~g} / \mathrm{dl}$ was noticed in 51 patients $(14.8 \%)$, however most of these patients remained hemodynomicaly stable only 15 patients needed transfusion because of hypotension. Ishikawa et al ${ }^{[18]}$ reported the incidence of drop in hemoglobin more than $1 \mathrm{~g} / \mathrm{dl}$ in $20.8 \%$ patients which is consistent with our study.

In a study by William et.al [7] a post-biopsy decrease in hemoglobin of $\geq 1.0 \mathrm{~g} / \mathrm{dl}$ was observed in $46 \%$ (222 of 478) of cases and a decrease of $\geq 2.0 \mathrm{~g} / \mathrm{dl}$ was observed in $9.6 \%$ (46 of 478 ) of cases. In biopsies with a complication, a postbiopsy decrease in hemoglobin of $\geq 1.0 \mathrm{~g} / \mathrm{dl}$ was observed in $89 \%$ (63 of 71) of cases (uncomplicated versus complicated, $P<0.0001)$ and a decrease of $\geq 2.0 \mathrm{~g} / \mathrm{dl}$ was observed in $48 \%$ (34 of 71 ) of cases (uncomplicated versus complicated, $P<0.0001)$. These results reveal little less incidence of greater than 2 gram/dl drop in haemoglobin than our study.

Hematoma: was the third most common complication in our study, 33 patients (9.6\%) developed post biopsy hematoma (Table-2). The incidence of hematoma has been reported as high as $33 \%{ }^{[19]}$. None of the patients required any surgical procedure after biopsy which is reported in international literature as $0.1 \%{ }^{[7]}$
Arteriovenous fistula: - as a complication of renal biopsy was seen in 3 patients $(0.9 \%)$ (Table-2). The incidence of AV fistula as a complication of renal biopsy has been reported as $0.4 \%{ }^{[19]}$.

Infection: - in the form of pylonephritis was seen in 3 patients $(0.9 \%)$ in our study. This patient was a 40 year old male and two females in 30s who after in first week after biopsy presented with chills and rigors with high grade fever and abdominal pain. All the three patients managed with $\mathrm{i} / \mathrm{v}$ antibiotics improved and were discharged within two weeks of hospital stay (Table-2). The incidence of infection as a complication has been reported as $3.9 \%{ }^{[20]}$. 
Table 4. Showing relation between complications and Age, Gender, Hypertension PT. it shows patients with prolonged PT have significantly higher incidence of blood loss $(p=0.035)$.

\begin{tabular}{|c|c|c|c|c|c|c|c|c|c|}
\hline & & & $\begin{array}{l}\text { Gross } \\
\text { Hematuria }\end{array}$ & Pain & Infection & Hematoma & $\begin{array}{l}\text { AV } \\
\text { Fistula }\end{array}$ & $\begin{array}{l}\text { Hypote- } \\
\text { nsion }\end{array}$ & $\begin{array}{l}\text { Need for } \\
\text { Blood } \\
\text { Transfusion }\end{array}$ \\
\hline \multirow{7}{*}{ Age (yr) } & \multirow[t]{2}{*}{$<=18$} & $\mathrm{~N}$ & 18 & 27 & 0 & 3 & 3 & 6 & 3 \\
\hline & & $\%$ & 28.6 & 42.9 & 0.0 & 4.8 & 4.8 & 9.5 & 4.8 \\
\hline & \multirow[t]{2}{*}{19 to 45} & $\mathrm{~N}$ & 45 & 84 & 3 & 21 & 0 & 9 & 9 \\
\hline & & $\%$ & 21.1 & 39.4 & 1.4 & 9.9 & 0.0 & 4.2 & 4.2 \\
\hline & \multirow[t]{3}{*}{$>45$} & $\mathrm{~N}$ & 6 & 60 & 0 & 9 & 0 & 0 & 3 \\
\hline & & $\%$ & 8.7 & 43.5 & 0.0 & 13.0 & 0.0 & 0.0 & 4.3 \\
\hline & & $P$ value & 0.243 & 0.924 & 0.734 & 0.644 & 0.107 & 0.304 & 0.994 \\
\hline \multirow{5}{*}{ Gender } & \multirow[t]{2}{*}{ Male } & $\mathrm{N}$ & 39 & 84 & 3 & 21 & 0 & 9 & 12 \\
\hline & & $\%$ & 18.6 & 40.0 & 1.4 & 10.0 & 0.0 & 4.3 & 5.7 \\
\hline & \multirow[t]{3}{*}{ Female } & $\mathrm{N}$ & 30 & 57 & 0 & 12 & 3 & 6 & 3 \\
\hline & & $\%$ & 22.2 & 42.2 & 0.0 & 8.9 & 2.2 & 4.4 & 2.2 \\
\hline & & $\mathrm{P}$ value & 0.634 & 0.814 & 0.423 & 0.844 & 0.212 & 0.968 & 0.372 \\
\hline \multirow{5}{*}{$\begin{array}{l}\text { Hyper- } \\
\text { tension }\end{array}$} & \multirow[t]{2}{*}{ Yes } & $\mathrm{N}$ & 30 & 63 & 0 & 15 & 3 & 9 & 12 \\
\hline & & $\%$ & 17.9 & 37.5 & 0.0 & 8.9 & 1.8 & 5.4 & 7.1 \\
\hline & \multirow[t]{3}{*}{ No } & $\mathrm{N}$ & 39 & 78 & 3 & 18 & 0 & 6 & 3 \\
\hline & & $\%$ & 22.0 & 44.1 & 1.7 & 10.2 & 0.0 & 3.4 & 1.7 \\
\hline & & $\mathrm{P}$ value & 0.577 & 0.476 & 0.330 & 0.822 & 0.305 & 0.607 & 0.154 \\
\hline \multirow{5}{*}{$\begin{array}{l}\text { Proth- } \\
\text { rombin } \\
\text { Time }\end{array}$} & \multirow[t]{2}{*}{$>13$} & $\mathrm{~N}$ & 15 & 51 & 0 & 12 & 3 & 9 & 12 \\
\hline & & $\%$ & 12.2 & 41.5 & 0.0 & 9.8 & 2.4 & 7.3 & 9.8 \\
\hline & \multirow[t]{3}{*}{$<=13$} & $\mathrm{~N}$ & 54 & 90 & 3 & 21 & 0 & 6 & 3 \\
\hline & & $\%$ & 24.3 & 40.5 & 1.4 & 9.5 & 0.0 & 2.7 & 1.4 \\
\hline & & $\mathrm{P}$ value & 0.121 & 0.924 & 0.457 & 0.959 & 0.179 & 0.247 & 0.035 \\
\hline
\end{tabular}

\section{Conclusion}

Renal biopsy is one of the most important diagnostic modality with nephrologists. The complications do occur with the procedure, but with proper pre and post procedure management they can be reduced significantly if not eliminated. in our study There was increased incidence of gross hematuria and hypotension in patients with prolonged PT with $\mathrm{P}$ value $=0.035$. There was no mortality in our study and no surgical intervention was needed for any complication.

\section{Bibliography}

1. Iversen P, Brun C. Aspiration biopsy of the kidney. 1951. J Am Soc Nephrol. 1997;8:1778-1787, discussion 1778-1786.

2. Alwall N. Aspiration biopsy of the kidney, including i.a. a report of a case of amyloidosis diagnosed through aspiration biopsy of the kidney in 1944 and investigated at an autopsy in 1950. Acta Med Scand. 1952;143:430-435
3. Tisher CC. Clinical indication for kidney biopsy (chaps 3) in Renal Pathology (2nd ed) edited by Tisher CC, Brenner BM, Philadelphia, JB Lippincott Company 1989, pp75-84.

4. Pirani CL. Evaluation of kidney biopsy specimens. In Clinical indications for kidney biopsy. In Renal Pathology: with clinical and functional correlations. 2nd Ed. 'Fisher CG and Brenner 13M eds. JB Lippincott Company; Philadelphia, 1994, p 85-115

5. Madaio MP. Renal biopsy. Kidney Int; 38: 529-543, 1990.

6. Tisher CC, Croker 13P. Indications for and interpretation of the renal biopsy: Evaluation by light, electron and immunefluorescence microscopy. In: Diseases of the kidney, $5^{\text {th }}$ ed., edited by Schrier RW, Gottshalk CW, Boston, Little, Brown and Co, 1997, pp 485-510.

7. William L. Whittier and Stephen M. Korbet Section of Nephrology, Departm- 
ent of Medicine, Rush-Presbyterian-St. Luke's Medical Center, Chicago, Illinois J Am Soc Nephrol 15: 142-147,2004

8. Lefaucheur C, Nochy D, Bariety. J Nephrol Tiler. 2009 Jul: 5(4):331-9

9. Korbet SM: Percutaneous renal biopsy. Semin Nephrol 22: 254-267,2002

10. Diaz-Buxo JA, Donadio JV Jr: Complications of percutaneous renal biopsy: An analysis of 1,000 consecutive biopsies. Clin Nephrol 4: 223-227, 1975

11. Christensen J, Lindequist S, Knudsen DU, Pedersen RS: Ultrasound-guided renal biopsy with biopsy gun technique-efficacy and complications. Acta Radiol 36: 276279, 1995

12. Hergesell O, Felten H, Andrassy K, et al: Safety of ultrasoundguided percutaneous kidney biopsy-retrospective analysis of 1090 consecutive cases. Nephrol Dial Transplant 13:975-977, 1998.

13. Preda A, Van Dijk LC, Van Oostaijen JA, et al: Complication rate and diagnostic yield of 515 consecutive ultrasound-guided biopsies of renal allografts and native kidneys using a 14-gauge Biopty gun. Eur Radiol 13:527-530, 2003.

14. Whittier WL, Korbet SM: Timing of complications in percutaneous kidney biopsy. J Am Soc Nephrol 15:142-147, 2004.

15. Bolton WK: Nonhemorrhagic decrements in hematocrit values after percutaneous renal biopsy. JAMA 238: 1266-1268, 1977

16. Burstein DM, Korbet SM, Schwartz MM: The use of the automatic core biopsy system in percutaneous renal biopsies: A comparative study. Am J Kidney Dis 22: 545-552, 1993

17. Khajehdehi P, Junaid SM, SalinasMadrigal L, Schmitz PG, Bastani B: Percutaneous renal biopsy in the 1990s: Safety, value, and implications for early hospital discharge. Am J Kidney Dis 34: 92-97, 1999

18. Ishikawa E, Nomura S, Hamaguchi T, Obe T, Inoue-Kiyohara Oosugi K, Katayama K, Ito M. Clin Exp Nephrol. 2009 Aug; 13(4):325-31

19. Carlo Manno, Giovanni F.M. Strippoli, Loredana Arnesano, Carmen Bonifati, Nicla Campobasso, Loreto Gesualdo, and Francesco P. Schena Kidney International, Vol. 66 (2004), pp. 1570-1577.

20. Prakash J, Singh M, Tripathi K, Rai US. Complications of percutaneous renal biopsy. Journal of the Indian Medical Association. 1994 Dec; 92(12): 395-6. 